\title{
БРЕСТСКИЙ НАРОДНО-ЦЕРКОВНЫЙ СЪЕЗД 1928 ГОДА
}

\section{В. С. МИСИЮК}

\section{Брестский государственный технический университет, г. Брест, Беларусь}

На территории Брестчины неоднократно имели место события, связанные с историей украинской церкви. Изучены они относительно слабо. Это справедливо как в отношении значительных событий, таких как Пинский собор 1942, так и более локальных. Тема украинского народно-церковного съезда в Бресте 1928 года встречается в трудах историков церкви Ивана Власовского [3], Владимира Борисевича [1], Владимира Рожко [8, 9], Тимофея Миненко [7], Надежды Стоколос [11], а также исследователя межвоенного периода Олега Власюка [4]. Значение брестского съезда определяется с одной стороны позициями, характерными для всего украинского православного движения межвоенного периода во Второй Речи Посполитой. Эта мысль повторяется неоднократно. В работе «Мартирология украинских церквей» брестский съезд приравнивается к съезду в Владимире-Волынском [6, с. 1029]. О решеннях съезда в Бресте тогдашний журналист писал: «В большинстве подтверждают все постановления съезда в Луцке» [2, с. 94]. Большинство упомянутых исследователей акцентировало внимание на умеренном характере события и предъявляемых требований. Иван Власовский на первое место поставил церковную практику - «умеренные притязания частичной украинизации богослужения» [3, с. 54]. Надежда Стоколос также акцентировала внимание на том, что съезд прежде всего обратил внимание на литургию и делопроизводство, «принял решения по вопросам языка церковных служб, которые отличались сдержанностью и умеренностью» [11, с. 25]. Подобные характеристики свидетельствуют о нерадикальном, консервативном характере украинского церковного движения в целом, последовательности требований его представителей. Участники признавали высокий общественный авторитет церкви, моральную пользу участия ее представителей в политической жизни: «Истинный пастор не должнен работать на благо какой-то партии и всякую партию обязан «христианизировать», то есть просвещать духом евангельским правды и любви» [2, с. 94]. В общем постулаты съезда выдержаны в духе идеологии христианской демократии. С другой стороны, сама по себе возможность проведения съезда факт значительный, тем более на фоне запрета аналогичного съезда в Ровно. Тимофей Миненко подчеркивал, что благословения на проведение съезда со стороны правящего иерарха у организаторов не было [7, с. 72]. А вот по мнению Олега Власюка брестский съезд проводился не вопреки позиции владыки, а при его молчаливом нейтралитете [4, с. 111]. Владимир Борисевич обратил внимание не столько на отстутствие критики со стороны владыки, сколько на то, что он принял и выслушал делегацию съезда [1, с. 129]. Журналист газеты «Селянський шлях» считал, что брестский съезд выделялся от аналогичных требованием соблюдения духовенством нейтралитета на предстоящих выборах в Сейм. Как видно, организаторы съезда проявили заметную выдержку, пытаясь сохранить идеологический нейтралитет.

Предание церкви национального характера выглядит революционно, нетрадиционно. Что вызвает естественное неприятие изменений со стороны консервативной части церкви. При этом нельзя забывать, что возникновение национально-освободительного движения было обусловлено противодействием ассимиляторской колониальной политике, в том числе религиозной. Из записки Никандра Котовича известно, что в середине XIX века духовенство активно использовало украинский язык как в быту, так и в проповедях, литургические тексты читали с украинским произношением [10, с. 161-168]. Имперская политика предусматривала всестороннюю русификацию церковной жизни, разрушение связей 
духовенства с регионом. Представленная таким образом украинизация церкви была возвращением к истокам, обновлением, возрождением церкви. Неудивительно, что в завершении брестского народно-церковного съезда звучал следующий призыв: «восстановить славные традиции Украинской православной церкви и возродить ее к жизни» [5, с. 13]. Именно так воспринимали этот процесс представители национального движения. Естественно, что в украинском церковном движении проявлялись сильные модернизационные тенденции, желание сделать национальные институты, в том числе и церковь, финансово крепкими и независимыми, соответствующими высокому образовательному уровню его представителей, расширить рамки социальной миссии церкви.

Можно было бы предположить, что государственная администрация приветствовала все инициативы, связанные с развитием церковной жизни, укрепления позиции церкви счет леворадикальных идей. Но факты свидетельствуют о другом. Как упоминалось ранее, съезд в Ровно воеводская администрация провести не разрешила. Полесский воевода выслал 30.04.1927 г. поветовым старостам распоряжение по вопросу воспрепятствования распространения программы Украинского церковного съезда в Луцке, который должен был состояться 5 июня 1927. Несмотря на трудности, в луцком съезде приняли участие 19 делегатов из южных поветов Полесского воеводства. Народно-церковный съезд в Бресте стал логическим продолжением луцкого съезда. В регионе к тому времени уже имелись соответствующие предпосылки. Инициатором проведения народно-церковного съезда была среда просвитян Полесского воеводства. 29 августа 1926 на съезде «Просвита на Полесье» делегат из Дрогичинского повета поднял вопрос использования в церковной жизни украинского языка. В декабре 1927 года на собрании руководителей читален Дрогичинского повета заместитель председателя организации М. Крижановський отдельно подчеркнул, что он поддерживает украинское церковное движение. Именно «Просвита» знакомила местное население с национальными инициативами, которые касались церковного жизни. Общество разослало в свои читальные листовку под названием «Украинский церковный съезд». Также инициативу активно поддержали местные организации Украинского крестьянско-робочего социалистического объединений «Сельроб». Интересно, что произошедшему не помешало то, что инициативы развития национальной церковной жизни исходили от идеологического оппонента Сельроб - Общественного комитета на Полесье.

В разных источниках территорию, с которой съехались представители украинского народно-церковного съезда в Бресте, описывают по-разному. Журналист «Селянський шлях» называл среди поветов Брестский, Пружанский и Дрогичинский [2, с. 94]. Эта же информация присутствует в протоколе съезда [5, с. 10]. В. Миненко [7, с. 72], В. Рожко [8, c. 85], И. Власовский [3, с. 54] и О. Власюк [4, с. 111] упоминают Брестский, Пружанский и Кобринский поветы. К сожалению, поименный список участников недоступен, не дает возможность проверить упомянутую информацию. На съезд прибыли 52 делегата [2, с. 94]. Поскольку благословение на его проведение не было, то на мероприятии отсутствовали представители духовенства, хотя национально активных священников в регионе было немало. Стоит подчеркнуть, что организаторами съезда были будущие иерархи Украинской автокефальной православной церкви архиепископ Варлаам (Виктор Соловей) и епископ Платон (Павел Артемюк). Среди прочего, это говорит о том, что среди организаторов и участников были весьма воцерковленные люди. Почетным гостем съезда был лидер украинского церковного движения доктор Арсен Ричинский, редактор религиознопросветительской газеты «На варті». Именно по его инициативе был созван в Луцке Украинский церковный съезд.

Украинский народно-церковный съезд в Бресте проходил 15 января 1928. Открыто мероприятие молитвой «Отче наш». Прежде всего избран президиум, в состав которого вошли Виктор Соловей - председатель, Василий Рудицкий - заместитель председателя, Порфирий Силенко - секретарь. Присутствующим сообщено, что Общественный комитет на 
Полесье выслал приглашение полесском епископу Александру, однако, ответа не получил. Затем председатель съезда поприветствовал главу Украинского церковного комитета Арсения Ричинского. Далее были зачитаны приветствия, поступившие на адрес съезда. Озвучена повестка дня. Она состояла из следующих пунктов: «1. Современное состояние православной церкви Польши. 2. Дерусификация и соборность устройства православной церкви в Польше. 3. Подготовка пастырей-церковнослужителей. 4. Церковное хозяйство. 5. Проповедывание и обучение религии. 6. Организация приходских советов. 7. Информация с мест» [5, с. 11]. Из-за ограничений во времени председатель предложил совместить доклады 1 и 2, а также 4 и 6. Их предложено заслушать первым и вторым.

Арсений Ричинський выступил с докладом «Современное состояние православной церкви в Польше и устранение российского влияния, а также роль института собора в церковном устройстве». Церковная администрация в Польше, по его мнению, продолжала придерживаться наследия прежней российской церковно-административной системы. В результате чего становилась орудием русификаторской политики. Украинское духовенство подвергалось преследованиям со стороны Варшавской митрополичьей курии и давлению со стороны Российского национального объединения.

Доклад Павла Артемюка носил название «Церковное хозяйство и организация приходских советов». Докладчик констатировал, что в ведении церковного хозяйства нет норм и правил, царит хаос и беспредел. Нижнее духовенство, прихожане лишены права голоса, контроля за экономическими вопросами, что разрушает церковное хозяйство. Поэтому съезд призвал создавать в украинских приходах приходские советы, которые вместе с настоятелями будут заботиться о приходах.

Доклад Виктора Соловья назывался «Подготовка духовенства и псаломщиков». Выступающий отметил отсутствие надлежащей подготовки духовенства, которая бы давала им возможность выполнять пастырские обязанности в соответствии с современными условиями. В среде низового духовенства ощущалась нехватка богословского образования, знакомства с культурным наследием украинского народа, его историей и языком. Еще одной проблемой виделось угнетенное состояние низового духовенства, явившееся результатом деспотических отношений в церковной иерархии.

Василий Павенский в докладе «Проповеди и обучение религии в школе» констатировал полный упадок древней традиции проповедей на церковнославянский языке. Причиной является пренебрежение к естественной речи народа и использования языка в политических целях. Результатом такого отношения становится падение духовнорелигиозной ценности проповедей. Обучение религии в школах на территории Полесского воеводства велось на русском языке, молитвы учили на церковнославянский. В тоже время Кременецкой семинарии созданы все условия для подготовки преподавания Закона Божия в школе на украинском языке.

Общее решение съезда формировалось из предложений, которые были выдвинуты после каждого из выступлений. Арсен Ричинский предложил: а) выделить из состава епархии территорий с преобладающим украинским населением: Брестского, Кобринского, Дрогичинского, Пинского, Столинского, частично Пружанского, Лунинецкого и Косовского поветов, а также назначить на эту епископскую кафедру украинца; б) церковь должна сохранять все древние церковно-народные обычаи, в литургии и устройстве церкви, особенно такие особенности восточного христианства как соборность и выборность; в) в литургическом языке везде в Полесский епархии, где того хотят прихожане, должен быть украинский язык; г) выразить солидарность общественности украинскому духовенству, которое стало жертвой наступления русского шовинизма и политики церковных властей, выслать соответствующие протесты церковной и государственной администрации; д) гарантия обеспечения религиозных потребностей украинского населения украинским клиром является государственным долгом; е) если требования не будут выполнены и на территориях 
проживания украинцев будут назначаться на церковные должности враги украинского народа, съезд поручает начать процедуру создания Украинской православной церкви в Польше с отдельной организацией и епископатом; ж) съезд присоединяется ко всем решениям Украинского церковного съезда в Луцке, в частности, в вопросе разработки Украинским церквоным комитетом устава церкви; з) для обеспечения религиозных потребностей украинского населения провести второй церковный съезд; и) организовать филиалы Украинского церковного комитета в провинции; к) «обратиться ко всему православному духовенству с предостережением не вмешиваться в партийные и национальные споры» [2, с. 94]. После выступления В. Соловья предложены следующие пункты: а) только эмансипированное, морально совершенное, идейно воспитанное духовенство может отвечать высокой миссии возрождения Украинской Православной Церкви и преодолению опасности дисгармонии церковно-религиозной и культурнонациональной жизни верующих, переживающих волну национального возрождения; б) требовать, чтобы духовенство Полесской епархии готовилось к пастырской работе в украинских школах; в) добиваться реорганизации съезда псаломщиков в Бресте, поручив руководство и чтение лекций образованным украинским священникам; г) поддержать резолюцию Луцкого церковно-народного съезда по организации образования православного духовенства в Польше. Докладчик Василий Павенский предложил: а) ввести во всех приходах проповеди в праздничные и воскресные дни на понятном населению украинском языке; б) одновременно с курсами гомилетики и теологии проводить для духовенства курсы украиноведения; в) обязательно учить религии и молитвам в украинских начальных и средних школах на украинском языке; г) запретить использование проповедей в русификаторских целях [5, с. 8-9].

Прозвучало предложение Никанора Горщарука из Бреста о том, чтобы церкви в украинских приходах строились национальными архитекторами в соответствии с национальными традициями, а в консистории для оценки церковных объектов по проведению ремонтных работ должны были быть задействованы украинские специалисты. Михаил Василюк из Каменицы-Жиравецкой предложил обратиться к церковным властям с требованием, чтобы в Свято-Симеоновском соборе Бреста и филиальной церкви в Тришине были назначены священник и псаломщик, которые могли бы вести богослужение на украинском языке. В поддержку предыдущего предложения выступил делегат села Тришин Василий Яцив. Выступал также делегат из села Орепичи Марцевич, который попросил объяснить принципы работы приходских советов и введения украинского языка в церковную жизнь. Отвечал на последний вопрос Василий Павенский [5, с. 13].

По предложению Василия Павенского довести решение съезда епископу Александру поручено Общественному комитету на Полесье. Фактически эта обязанность возложена на председателя комитета М. Крижановского, председателя съезда В. Соловья и В. Павенского [3, с. 54]. В заключение Виктор Соловей подчеркнул важность «первой организованной попытки проявления активности православных мирян-украинцев Полесья» [5, с. 13]. Завершен съезд исполнением «Заповіт» на слова Тараса Шевченко.

Решения народно-церковного съезда в Бресте повлияли на то, что на совещании епископа Александра с духовенством Бреста принято решение пригласить с выступлением на будущий епархиальный съезд Виктор Соловья. Впоследствии епископ публично высказался за то, чтобы духовенство не навязывало русскую культуру местному населению и использовало украинский язык там, где того желают прихожане. Хотя до практической реализации тезисов украинского церковного движения было далеко, брестский съезд стал одним из важных шагов по созданию (при содействии Полесского епископа иерархии Украинской автокефальной православной церкви). 


\section{Литература}

1. Борисевич, В. Волинський пом' янник - Рівне: Рівненська друкарня, 2004 - 407 с.

2. Винниченко, В. Українці Берестейщини, Підляшшя й Холмщини в першій половині ХХ ст. - К.: [б.в.], 1997. - 288 с.

3. Власовський, І. Нарис історії української православної церкви: у 4 т., 5 кн. - Київ : Либідь, 1998. - Т. 4. : ХХ ст. - 367 с.

4. Власюк, О. «Східні креси»: під знаком польського орла - Луцьк: Волинські обереги, 2004. - $135 \mathrm{c}$.

5. Государственный архив Брестской области. - Ф. 1. Оп. 2. - Д. 2080.

6. Мартирологія українських церков / Упоряд. Осип Зінкевич, Олександер Воронин Торонто-Балтимор: Смолоскип, 1987. - Т. I: Українська Православна Церква : Документи, матеріяли, християнський самвидав України. - 1208 с.

7. Міненко, Тимофій Православна Церква в Україні під час другої Світової війни під час другої Світової війни, 1939-1945: Волинський період - Вінніпег, Львів : Вид-во Львівського музею історії релігії, 2000 - 111 с.

8. Рожко, В. Відродження української православної церкви на Волині. - Луцьк : Волинська книга, 2007. - 346 с.

9. Рожко, В. Нарис історії Української Православної церкви на Волині - Луцьк : Медіа, 2001. - $672 \mathrm{c}$.

10. Сергійчук, Володимир Етнічні межі і державний кордон України. - Тернопіль : Книж. журн. вид - во “Тернопіль”, 1996. - 179 с.

11. Стоколос, Н. Українізація православ’я: з історії Православної церкви у 20-30 pp. ХХ століття - К. : Міжнародна фінансова агенція, 1998. - 52 с.

Статья посвящена важному событию в истории украинского религиозного движения. Брестский церковный съезд 1928 года выражал настроения прихожан православной церкви проживающих на территории Полесской епархии. Во многом они перекликаются с феноменом обновленчества, охватившем Русскую православную церковь в начале XX века.

The article is devoted to an important event in the history of the Ukrainian religious movement. The Brest Church Congress of 1928 expressed the sentiments of the parishioners of the Orthodox Church living on the territory of the Polesie diocese. In many ways, they have something in common with the phenomenon of Renovationism that gripped the Russian Orthodox Church at the beginning of the 20th century. 